\title{
FEMINISM AND DISSIDENT FEMININITY IN POPULAR CULTURE. CHER'S ROLE AND THE ROLE OF RELIGION IN MOONSTRUCK
}

\author{
Orquídea Cadilhe ${ }^{1}$
}

\begin{abstract}
When looking at representations of women, one is faced with the way such representations were conditioned by the prevailing mentality of a particular age, that is to say, how they were 'framed' by it. In this article we start by carefully looking at how, in spite of having had frames imposed on them in a constraining way, women have successfully resisted and reworked them, shockingly catapulting traditional iconography to a new sphere; namely popular icons. A 'damsel in distress' is, definitely, a 'framed' woman. She has been, throughout history, a common archetype in myth. Always helpless, she is in need of being rescued by a male figure; an idea that must have done wonders to the egos of male writers and readers alike. For that reason, we will be looking at 'damsels in distress' along history. More specifically, we apply the notion of frame to representations of gender and explore how popular culture is frequently capable of 'unframing' those representations. Our case study is the 1987 post classical romantic comedy Moonstruck an intersemiotic and intertextual product with traces of both Cinderella, Little Red Riding Hood, and Puccini's opera La Bohème, three stories in which 'damsels in distress' play the main role in the plot in order to deconstruct the above mentioned stereotype of 'the damsel' with the 'help' of strong female characters, one of them being Loretta, the character played by Cher.
\end{abstract}

Keywords: Dissident femininity. Feminism. Deconstruction. Popular icons.

\section{FEMINISMO E FEMINILIDADE DISSIDENTE NA CULTURA POPULAR. A PERSONAGEM DE CHER E O PAPEL DA RELIGIÃO EM MOONSTRUCK}

\begin{abstract}
Resumo: Olhando para representações de mulheres ao longo dos tempos, deparamo-nos com o modo como estas foram condicionadas pela mentalidade dominante de uma determinada época, isto é, como elas foram "emolduradas" ou "enquadradas" por esta. Este artigo começa por cuidadosamente analisar como, apesar de terem-lhe vindo a ser impostas "molduras", as mulheres, resistem e trabalham-nas, acabando por provocantemente deslocar a iconografia tradicional para uma nova esfera, nomeadamente ícones da cultura
\end{abstract}

\footnotetext{
${ }^{1}$ Centre of Humanistic Studies, University of Minho, Braga, Portugal. E-mail: ocadilhe@ilch.uminho.pt.
} 
popular. Uma “donzela em perigo" é, definitivamente, uma mulher "emoldurada", uma que tem, ao longo da história sido um arquétipo. Sempre desprotegida, esta tem a necessidade de ser resgatada por uma figura masculina (ideia esta que deve ter alimentado maravilhosamente bem o ego de escritos e leitores masculinos). Por este motivo, analisaremos "donzelas em perigo" ao longo da história. Mais especificamente, aplicamos o conceito de "moldura" a representações de género e exploramos como a cultura popular é frequentemente capaz de "desmoldurar" tais representações. O nosso estudo de caso é a clássica comédia romântica $O$ Feitiço da Lua, um produto intersemiótico e intertextual com traços de Cinderela, O Capuchinho Vermelho e a ópera de Puccini La Bohème, três histórias nas quais "donzelas em perigo" desempenham o papel principal na história, capaz de desconstruir o acima mencionado estereótipo da "donzela em perigo" com "a ajuda" de personagens femininas empoderadoras, sendo uma delas a personagem de Cher.

Palavras-Chave: Feminismo dissidente. Feminismo. Desconstrução. Ícones Populares.

\section{'Damsels in Distress'}

One of the earliest portrayals of a damsel in distress is presented in the Greek myth of Andromeda. Princess Andromeda's mother claimed that she was more beautiful than all the water nymphs in the sea. Angered, the nymphs sent a giant sea serpent to terrorize the coast of the queen's country. When the king and queen asked the gods for advice on how to appease the nymphs, the gods said that they had to sacrifice their daughter. Rembrandt's Andromeda Chained to the Rocks depicts a nude Andromeda waiting for the sea serpent to eat her. Perseus (a human man, whom the gods had given wings) offers to save her as long as she marries him.

During Post-classical history, the damsel in distress is an archetypal character of medieval romances who is rescued from being imprisoned in the tower of a castle by a knight and is the young woman of fairy tales. In Modern history, more specifically during the $18^{\text {th }}$ century, this same damsel is a stock character in modern novels and in Gothic literature, where she is normally incarcerated in a castle or in a monastery (an example is that of Gretchen in Goethe's Faust). Along the $19^{\text {th }}$ century, the damsel in distress showed up in 
Victorian melodrama, which eventually influenced the cinema industry and many damsels in distress became the subject of many early silent films.

In 1933, the film King Kong told, yet again, the story of a beautiful woman and a scary monster, the Beauty and the Beast. Even though the two stories were written centuries apart, after comparing Rembrandt's Andromeda and the scene from King Kong where Ann Darrow is also tied and terrified as King Kong approaches her, one cannot but notice the similarities. Both women are representations of beauty in their time and are in a state of extreme danger because they were offered in sacrifice to monsters. In the case of Darrow, she has just arrived at Skull Island to shoot a film and is taken hostage by the natives who prepare her as a sacrifice to the ape Kong, the ruler of their jungle. She is, eventually, rescued by Jack Driscoll, the explorer that Carl Denham (the filmmaker) had taken with the crew to help them get to know the island.

In classical fairytales, prince charming is a character that comes to the rescue of 'a damsel-in-distress', usually a beautiful and innocent young woman who is facing a dangerous situation and is, therefore, in need of a male hero to engage in a quest to free her from either a villain, a monster, or an alien. Once the rescue is successful, the hero often obtains her hand in marriage. This damsel is to be found in classic fairy tales such as Snow White, Sleeping Beauty, Cinderella, and Little Red Riding Hood, stories in which the heroine is not in a position to do anything when her rescuer arrives other than stay in a comatose state. Postmodern and second wave feminist writers view the classic tales as editor Jack Zipes (1993) states, as "a male creation and projection" (ZIPES, 1993, p. 80) that "reflects men's fear of women's sexualityand of their own as well" (ZIPES, 1993, p. 81).

In fairytales, one of the figures that can put a damsel in distress is that of the wolf. In literature and culture, the wolf traditionally represents danger and destruction ${ }^{2}$. In many cultures, the identification of the warrior with the wolf led to the notion of 'lycanthropy', the mythic amalgamation of man and wolf. The Bible contains thirteen references to wolves and presents

${ }^{2}$ Yet, they are predators, and, therefore, have also become the symbol of warriors. 
them as metaphors of ambition and destruction that personify Satan. The Malleus Maleficarum (2007) states that the wolves are either agents of God sent to punish the sinners or agents of the Devil sent with the blessings of God to harass the believers and test their faith. In the Christian Western literature, the wolf represents the 'Devil' or the 'Demon' that runs after the 'sheep', that is, the believer. In Milton's Lycidas, for instance, the metaphor is obvious, "The hungry Sheep look up, and are not fed / But swol'n with wind, and the rank mist they draw / Rot inwardly and foul contagion spread: Besides what the grim Woolf with privy paw / Daily devours apace" (MILTON, 1983, p. 11). In canto I of Dante's Inferno, the pilgrim finds a she-wolf blocking the path that leads to a hill full of light (DANTE, 2009, p. 2). This female wolf represents the sin of concupiscence and incontinence and is prophesied by the shadow of Vigil to eventually be sent to Hell. In European tales of witch hunts from the beginning of the Early Modern Period, the witches are compared to wolves since, such as the latter, they wander in the woods. In present day folklore, as well as in popular literature and culture, the image of the wolf is significantly influenced by the stereotype of the "bad wolf" with origins in Aesop's, Perrault's and Grimm's fables.

Charles Perrault (1628-1703) is frequently labeled the founder of the modern fairytale since he was the first to have them published in the form of a book. Nevertheless, his work was influenced by previous fairytales, namely those of Marie-Catherine Le Jurnel de Barneville, Baroness d'Aulnoy. In 1690 she was already writing tales and was the first to call them 'fairytales'. As Marina Warner (1995) put it, Perrault has, in fact, adapted a folk tale in which a young lady finds a wolf on her way to her grandmother's house. The wolf tries to convince her to eat a piece of the grandmother and drink her blood; yet, she manages to escape when she claims she has to go out to urinate. He ties her to a rope and lets her out of the cabin. She manages to set herself loose and escapes. Perrault's version, in turn, ends with the grandmother and the granddaughter eaten by the wolf. The happy end of the original story is subverted because this girl is not smart enough. Perrault has explained the moral of the story as follows: 
Children, especially attractive, well-bred young ladies, should never talk to strangers, for if they should do so, they may well provide dinner for a wolf. I say 'wolf', but there are various kinds of wolves. There are also those who are charming, quiet, polite, unassuming, complacent, and sweet, who pursue young women at home and in the streets. And unfortunately, it is these gentle wolves who are the most dangerous ones of all (WARNER, 1995, p. 181).

More than a century later, the brothers Grimm would write two versions of The Little Red Riding Hood. The first is a version of Perrault's where the erotic details are omitted and the end is less dramatic since a hunter saves the young girl and her grandmother. In the second one, a sequel, the girl follows the path to the grandmother's house, the grandmother locks the door so that the wolf cannot enter and when he attempts to do so by going down the chimney, he falls into a pot of boiling water that the young girl uses as a trap.

In the 1970s, research done in Germany by critics and experts in the Grimm's collection started exposing the misogynist ideology behind the symbolism of the tales and denouncing how they helped spread repressive values advocated by the $19^{\text {th }}$ century bourgeoisie. The redeeming endings matched the mentality of the Enlightenment, which was detached from the religious way of thinking and advocated that one can learn from experience.

In their book Framing Women: Changing Frames of Representation from the Enlightenment to Postmodernism, editors Sandra Carrol, Birgit Pretzsch, and Peter Wagner (2004) draw attention to the confining roles used to frame women in contemporary Western society and contrast two periods, the Enlightenment and Postmodernism. The first places a coherent frame of meaning on issues, while the latter accepts and embraces contradictory frames and, therefore, a multitude of truths. By doing so, Postmodernism points to the fact that Enlightenment assumptions about women are still present in contemporary society.

Ana Gabriela Macedo (2017) considers that the concept of 'frame' is crucial to the understanding and discussion of identity politics and of 'representation', which, according to the latter, were always intrinsic to the critical debate of Feminism. Macedo argues that the strategies of postmodern 
denaturalization linked to the politicization of desire that Feminism claims as its own is a critical and ideologically assumed revisitation of memory that significantly contributed to a parodic subversion from the center, as pointed out by Linda Hutcheon (1989). Especially since the 1980s, a theoretical body of work was developed, which contributed to present history through the eyes of women. Such resulted in a more equitable mapping of the art, as well as in the inscription of difference and the feminine heteroglossia, in the canons of art. As Macedo (2017) states, contemporary feminist art can be understood as aesthetics of critical appropriation and one that questions the tradition that exhibits the dialogical tension between "registering", "reframing", and "resisting". As Macedo argues, “[...] the dialogue between framing and unframing [...] rejects standardization and critiques the cultural representation of women" (MACEDO, 2015, p. 83), the critic underlines the fact that both literary and visual narratives "[...] can provide a similar challenge to fixed codes of representation while transgressively 'unframing' women and thus 'reframing' the silences of history" (MACEDO, 2015, p. 83).

\section{Unframing the 'Damsels'}

As Kate Bernheimer, in her preface to Fairy Tales Reimagined Essays on New Retellings argues, "Scholars [...] provide transfixing narratives about the Marxist, postmodern, psychological, feminist, and aesthetic magnets in fairy tales, which rivet audiences worldwide in music, film television, literature, and fine art versions and inspire new versions to be produced at an immeasurable rate" (BERNHEIMER, 2009, p. 2).

According to Donald Haase (2004), Zipes' anthology The Trials and Tribulations of Little Red Riding Hood encourages and clarifies comparisons between versions and the historical analysis of the development of tales. Haase considers that Zipes' conclusions, as well as the organization and methodology of his work (which reveal the vital importance of comparing oral and literary versions in socio-historical contexts to understand the relationship between the tale and gender and socialization), significantly contributed to feminist studies of the fairy tale. The introductory study of the history of the tale confirmed that it reflects the civilizational process of 
western societies and that it had a main role in such process by reinforcing the ideology of the middle class. More specifically, Zipes showed that many adaptations are linked with cultural stances pertaining to the roles of males and females in society. He further refers how Perrault and the Grimm Brothers have produced versions of the Little Red Riding Hood that drastically changed the oral tale and erased the positive references to sexuality and feminine power. Such rereadings gave rise to rewritings of the tale. As Christa Mastrangelo Joyce puts it:

Contemporary women poets [...] explore and recreate the fairy tales. These poets entered a literary genre long dominated by men and claimed it as their own [...] They have stretched the original boundaries of the tales [...] reversing or highlighting many of the perverse misogynistic views with which the source texts were imbued (JOYCE, 2009, p. 31).

Angela Carter's tale "The Company of Wolves", published in the collection of short fiction The Bloody Chamber (1979), is an example of such rewritings, as we will be able to further explore. Carter deviates from the moralistic warnings of the Grimm Brother's and Perrault's tales and portrays a feminist protagonist who is no 'damsel in distress' about to become an easy prey. Instead, she is an independent subject, in control of her sexuality and in charge of her fate.

The damsel-in-distress, as an example of differential treatment of genders in literature, works of art, and film, which perpetrates regressive and patronizing myths about women, has particularly become a stock figure of melodrama.

\section{The 'Damsel' and the Wolf According to Shanley}

To be moonstruck is to acknowledge the wolf within, to give its place; to grant that howling at the moon is the foundation of social institutions. - Kathleen Rowe, The Unruly Woman: Gender and the Genres of Laughter (1995). 
In Moonstruck, the singer, actress, and television personality Cher plays the character of Loretta Castorini alongside Nicolas Cage and Olympia Dukakis. The plot revolves around the lives of Rose Castorini (Dukakis) and her 37-year-old daughter Loretta who is a widow (Cher). They are both at turning points in their relationships with men.

Loretta has accepted the marriage proposal of Johnny, a childish, insecure man and Rose is aware of her husband's (Cosmo) extramarital affair. The latter is a very assertive woman, who seems to know men as the palm of her hand. A series of situations throughout the story illustrate my interpretation of Rose's personality.

At the beginning of the film, Cosmo lets Rose know that Loretta is about to get married and that he dislikes the groom, to which she replies, "You're not gonna marry him, Cosmo" (SHANLEY, 1988, p. 22). And turning to her daughter, "Do you love him, Loretta?" (SHANLEY, 1988, p. 22) Loretta answers, "No" (SHANLEY, 1988, p. 22) and she comments, "Good. When you love them, they drive you crazy cause they know they can. But you like him?" (SHANLEY, 1988, p. 22). Another instance in which she presents herself as a woman 'on top' is when Cosmo refuses to pay for the wedding arguing he has no money and she answers, "You're rich as Roosevelt. You're just cheap, Cosmo" (SHANLEY, 1988, p. 22). And addressing Loretta, she makes a highly interesting comment, 'He thinks if he holds on to his money, he will never die' (SHANLEY, 1988, p. 23). Rose has no problem telling Cosmo exactly what goes on in her mind. At a family dinner, Rose's father starts feeding food to the dogs from under the table. Rose immediately realizes it and utters, 'Old Man, if you give another piece of my food to those dogs, I'm gonna kick you till you're dead!' (SHANLEY, 1988, p. 45), making the point she is note easily deceived. The screenplay reads, "The Old Man reverses direction and heads back to his chair. He sits down and starts to eat" (SHANLEY, 1988, p. 45).

Two other traits of Rose's personality are wisdom and the capability of offering unconditional love. One night, Cosmo is asleep and she looks at him while he lightly snores and says to herself, "You drank too much and now you sleep too hard, and later you'll be up when you should be down" (SHANLEY, 1988, p. 46). Then she kisses his cheek. One night, when Loretta is out with her fiancées' brother, Ronny, and Cosmo meets with his lover, Rose 
decides to have dinner at a restaurant. Once there, she observes a man and a much younger woman quarreling and, eventually, she leaves the restaurant (in an earlier scene this same man was at the same restaurant with another young woman and a similar situation took place). When the man exchanges eyesight with Rose, he apologizes for the disturbance he has caused and invites her to have dinner with him. During their conversation, she asks him why men chase women. He answers "Nerves" (SHANLEY, 1988, p. 69), to which she replies, "I think it's because they fear death" (SHANLEY, 1988, p. 69). He admits that what makes him invite young women out is the fact that he wishes he were young. After exiting the restaurant, he walks her home and when he asks her if she could invite him in, she says, "I can't invite you in because I'm married and because I know who I am" (SHANLEY, 1988, p. 77). He comments he is a little cold and she tells him he is a little boy who likes to be bad and that she is too old for him. He counterargues that he is too old for himself and they kiss on the cheek.

When Johnny arrives from Palermo, she asks him why men chase women, to which he replies maybe it is because when God took a rib from Adam, he left a hole there, a place where there used to be something, and the women have that. So, maybe a man is incomplete without a woman. Her next question is why would a man need more than one woman. After some thought he answers it is maybe because he fears death, to which she agrees. Johnny decided to marry Loretta because since his mother was very ill, he needed someone to replace her. Once she recovered, he decided to cancel the wedding.

Cosmo comes home late after being at the opera with his mistress and Rose asks him where he was. He replies that he does not know, nor does he know where he is going. Nevertheless, he turns to Johnny and warns him that he must keep his eyes open since he has met his daughter with Johnny's brother at the opera. Rose simply tells Cosmo that he must be aware that he will die no matter what.

By the end of the film Cosmo says, "A man [...] understands one day [...] that his life is built on nothing. And that's a bad, crazy day" (SHANLEY, 1988, p. 92). To which Rose replies, "Your life is not built on nothing. Ti amo" (SHANLEY, 1988, p. 92). The film scripts says, “Their eyes meet. It's the first 
time he's been able to hold her gaze in this whole story" (SHANLEY, 1988, p. 92).

Making use of parodic laughter, the film ridicules the faith of the damsel in fairytales and, up to a certain extent, in the melodrama, by subverting the messages of the original stories to 'unframe' and empower the female characters. There is an inversion of gender hierarchy as the heroin (Loretta) wakes up to her latent sexuality. In spite of being engaged, she meets and falls in love with her fiancées' brother, a baker with a tempestuous character who goes by the name of Ronny (Cage). Such awakening is symbolically linked to the image of the wolf, a subject of distress since it is a predator feared by the female characters in the classic tales. In the film, just as in Angela Carter's “The Company of Wolves", the wolf is presented as scary but also as an object of attraction and, ultimately, of happiness. This perspective is a different way of approaching sexuality and the male and female roles in society. The female protagonist becomes a confident and selfpossessed woman brought about by a transformation.

Moonstruck moves, as Rowe puts it, between the pathos of the melodrama, essentially represented by the story inside the story that is the opera La Bohème, and the irony and humor of the postclassical romantic comedy (ROWE, 1995, p. 192). Thematic tensions are alternatively established between night-day and life-death. The soundtrack reinforces such tension. The film starts and finishes with the song That's Amore by Dean Martin and, in between, one can listen to Puccini's melodies. Nevertheless, the genre that ultimately wins over is the comedy and this is the reason that Dean Martin can be heard both in the beginning and at the end of the film. As we will see, the comedy ends up transforming the melodramatic themes and motives of La Bohème and giving emphasis to the female characters, as the most positive elements of melodrama are withdrawn.

The whole film, right from the first scenes, emphasizes how people can be 'dead' while alive. The first scene shows the entrance of the Metropolitan Museum of Art at night where posters are being displayed announcing La Bohème. The next morning Loretta is on her way to work (a funeral home) when a truck reading 'Metropolitan Opera - Scenic Shop' passes by. Intuitively, the spectator infers that Puccini's opera will be linked 
to the character's story. About this scene Elizabeth Ford and Deborah Mitchell write:

Before you know her problem, you instinctively know Loretta's problem. She's detached from the life swirling around her. Loretta is on a search for a state of mind that will bring her harmony. [...] Loretta [...] doesn't see life, and literally, doesn't see herself (FORD AND MITCHELL, 2004, p. 182-183).

The idea that the character is in a lethargic stage of mind is reinforced by the fact that she works at a funeral house. Evoking the grotesque, the undertaker proudly tells Loretta that he makes the dead look better than they had in real life while the old ladies mourning in the wake room say that he is a genius. The florist delivers roses to the dead man and Loretta comments how the person who bought them has just spent money on something that is going to end up in the trash. Nevertheless, she admits that she likes flowers and when he offers her a rose her eyes brighten up, letting her romantic side surface and hinting at the fact that something is about to change. Later, during a full moon, Loretta takes Johnny to the airport. As Ford and Mitchell say, the moon usually stands for "a portent of change" (FORD and MITCHELL, 2004, p. 183). In one of the next scenes Loretta is at a wine store where the owners, an elderly couple, are having an argument: she is accusing him of looking at another woman as a wolf but, the problem is quickly trivialized when he says he sees in her the woman he married. She blushes, as she tells him she sees a wolf in everyone. The spectator can only conclude that there is nothing wrong about 'having a wolf' inside each and every one of us.

When Loretta meets Ronny for the first time, he expresses his anger for having a wooden hand. He tells the story about how he chopped his own hand when his brother distracted him from his work. As a consequence, his bride left him. He feels highly frustrated because now his brother has a bride (Loretta) and he does not. Loretta reverts Ronny's logic and considers he wanted to escape his bride and, therefore, self-inflicted such pain, an interpretation similar to that of Zipes when he reads the narratives of fairy tales as a result of men's and women's fears concerning their sexuality. In the 
same line, William Day considers that such a hand symbolizes castration (DAY, 2003, p. 20).

When Ronny invites Loretta to his apartment, she makes him eat a medium-rare steak in spite of his claim that he prefers them well done. She replies, "You'll eat this one bloody to feed your blood" and after trying it he really loves it, which shows that by then she already knows his inner self better than he does. Loretta concludes that he is trying to hide the fact that he is a wolf (to her and to himself). The scene shows the viewer how well they know each other in spite of having just met. She tries to avoid engaging in a relationship with Ronny but ultimately accepts his invitation to go to the opera with him.

In order to get ready for the date, Loretta goes to the Cinderella Beauty Shop for a makeover. After telling the hairdresser she wants to dye her hair, in an intertextual reference to Cinderella, the script reads, "Transformational music starts here and continues through the following scenes. This music should convey that Loretta is turning from a frumpy pumpkin into a sleek and beautiful coach" (SHANLEY, 1988, p. 61). In the film the music can be heard while Loretta exits the hairdresser and is on her way to the boutique, as well as from the time she leaves the boutique until she arrives home. She undergoes her 'transformation', as Cinderella does, to go to the ball. As she exits the boutique, she bumps into two nuns who tell her "Be careful": Loretta is on her way to 'sin'. Nevertheless, the scene is lightly presented and is humorous. Laughter breaks hierarchies and a new order is about to be established. As Ford and Mitchell claim, "Unlike all the nearsighted princes who only recognize Cinderella when the slipper fit, Ronny recognizes Loretta's true self before her transformation" (FORD AND MITCHELL, 2004, p. 183) since they 'wake up to life' when they recognize they had been 'dead'. After watching Puccini's La Bohème, they bond even more.

While telling his story to her, Ronny says, "I have no life. My brother took my life" (SHANLEY, 1988, p. 31) and later on, when in bed, he exclaims, "I was dead" (SHANLEY, 1988, p. 41), to which Loretta replies, "I was dead, too" (SHANLEY, 1988, p. 41). After having attended the opera and before going to Ronny's apartment for a second time, Ronny tells Loretta "You run to the wolf in me, that don't make you no lamb" (SHANLEY, 1988, p. 79) and the film script 
reads, "They kiss. When they part there is a drop of blood on Loretta's lips" (SHANLEY, 1988, p. 41). Such a reference to the animalesque and to the loss of virginity invites for intertextual readings between the Little Red Riding Wood and The Company of Wolves. The following dialogue ${ }^{3}$ reinforces the link:

\section{RONNY \\ Your blood.}

LORETTA

All my life I have never reached a man. I knew that I would reach my husband, but I took my time and he was dead.

RONNY

Loretta.

LORETTA

I want to cut you open and crawl inside of you. I want you to swallow me.

RONNY

I've got you.

LORETTA

Get all of me. Take everything.

RONNY

What about Johnny?

\section{LORETTA}

You're mad at him, take it out on me, take your revenge on me! Take everything, leave nothing for him to marry! Hollow me out so there's nothing left but the skin over my bones. Suck me dry!

RONNY

Alright. Alright. There will be nothing left.

\footnotetext{
${ }^{3}$ The dialogue up to "Get all of me. Take everything" (inclusive), can be read in the script but was not used in the film. Nevertheless, it says something about the author's intentions and it helps understand the themes of the film, confirming what certain scenes hint at.
} 
"Their eyes are boiling with fierce animal tears. They have opened their souls to each other and they are coming together" (SHANLEY, 1988, p. 42).

The above dialogue rewrites the story of the Little Red Riding Hood in the manner Carter did with her story "The Company of Wolves". Carter's narrator says, "[...] her red shawl [...] has the ominous if brilliant look of blood on snow [...]. She is an unbroken egg; she is a sealed vessel; [...] she does not know how to shiver" (CARTER, 1979, p. 3). Loretta also dresses in red in a cold winter night to meet her 'wolf' and, up to a certain extent, was a virgin until she met Ronny since she had not fully lived until then (thus the blood on her lips).

Just as the girl in Carter's tale expresses her sexual desire for the 'wolf' and invites him to possess her by saying "What shall I do with my shawl? [...] What shall I do with my blouse?" (CARTER, 1979, p. 138), Loretta also expresses her desire for Ronny. While Grimm's little girl is saved because the hunter cuts the wolf's belly, Loretta is the one who wants to cut Ronny, crawl inside him, and asks him to 'swallow' her (at this point she is in the position of saving him). She is not the fragile, unprotected character that is caught in a trap in the traditional fairy tale. In fact, the next day, she fears she might have committed a mistake and when Ronny claims he is in love with her, her answer is "Snap out of it!" (SHANLEY, 1988, p. 51) followed by a slap on his face.

Carter's character is described as a “[...] strong minded child [...] quite sure the wild beasts cannot harm her [...]" (CARTER, 1979, p. 2-3) who meets with the hunter and "Soon they were laughing and joking like old friends" (CARTER, 1979, p. 3). About the heroin in "The Company of Wolves", says Catherine Orenstein, "The heroine claims a libido equal to that of her lascivious stalker and becomes a wolf herself" (ORENSTEIN, 2004, n/p) ${ }^{4}$. In Moonstruck, the dialogue in the scene where Ronny is trying to convince Loretta to enter his apartment is shorter than in the script. It reads, "Don't try to live your life out to somebody else's idea of sweet happiness. Don't try to live on milk and cookies when what you want is meat! Red meat just like me!

${ }^{4}$ http://www.msmagazine.com/summer2004/danceswithwolves.asp. 
It's wolves run with wolves and nothing else!" (SHANLEY, 1987, p. 81). When these women meet the 'wolf', they meet their soul mate and a transformation takes place. The human being is, thus, perceived as having a fluid identity.

In Moonstruck, as in Carter, the beast (werewolf) is initially an icon of fear but also of undeniable attraction: The Little Red Riding Hood of Carter deliberately arrives last at her grandmother's house to lose the bet and allow the hunter to kiss her, while Loretta, in spite of showing some regret for having slept with Ronny ("You've got those bad eyes like a gypsy! Why didn't I see it yesterday!") (SHANLEY, 1988, p. 50), follows him to his apartment after the opera, instead of heading home as they were supposed to do, "This is your place [...]. This is where we're going!" (SHANLEY, 1988, p. 79). Loretta had to know she was not on her way home; she simply ignored it since she, as the Little Red Riding Hood, wanted something she did not dare to utter.

Jessica Tiffin claims that the wolves are trapped in the folktale that defines them, as strongly as these women are and as such, they are both feared and attacked by their prey, that is to say, they are both perceived as monsters in the light of a dominant ideology which reflects a specific concept and are a threat to the patriarchal power (TIFFIN, 2009, p. 65). Both Loretta and Carter's Little Red Riding Hood challenge convention and gender stereotypes and are, therefore, considered transgressors and marginal by the dominant ideology. By inverting the traditional male and female roles, such stories represent stories of female empowerment, and thus, 'reframe' women.

Loretta $^{5}$ is responsible for 'disorder' and 'assaults' to male authority in comic scenes in which the way the male characters think is ridiculed, alluding to the social and literary traditions of the carnivalesque. Throughout the film, the viewer is constantly reminded that death is crucial for a new order to be born and that Loretta, presented as the unruly woman, is suspending 'normal' rules of society (not in terms of social strata as in the case of Mikhail Bakhtin's concept of carnival ${ }^{6}$ but in terms of gender). Gender

${ }^{5}$ The name Loretta means 'little victory'.

${ }^{6}$ The Russian theoretician Mikhail Bakhtin in Problems of Dostoevsky's Poetics (originally published in 1929). Bakhtin (1999) challenges the canonical historicist critique, which sees the novel as a homogeneous representation of reality that expresses the direct worldview of an author. In opposition, he develops the concept of the polyphonic novel, which does not directly comply with the ideology of the 
inversion is observed when Johnny and Loretta listen to Perry, a middle-aged professor, being humiliated by one of his female students who is having dinner with him at an Italian restaurant. Johnny laughs at the situation and tells Loretta that a man who does not control his woman is funny. In turn, Loretta ridicules his remark when she replies that their argument has to do with their age difference. In the same scene Loretta chooses what Johnny is going to eat because he wants to make a poor decision and eat something that is going to make him feel sick during the flight he is about to catch. Before leaving, Johnny proposes but without having a ring to offer Loretta and she asks him to give her his pinky ring, which makes him feel sad. On the way to the airport she, once again, reinforces her dominance over him when she makes him agree on scheduling the wedding date, despite his insecurity and against his will. Johnny expresses his willingness to get married after his mother passes away, which seems to imply that he is thinking about getting married to have a wife play the role of his mother. Later, on the phone from Palermo, he comments his mother is dying but Loretta does not believe him because, as she tells her mother, "She's dying. But I could still hear her big mouth" (SHANLEY, 1988, p. 28). She feels the need to talk to him as if she were talking to a child; therefore, she reminds him, “And don't stand directly under the sun. You've got your hat, use your hat” (SHANLEY, 1988, p. 28).

When Ronny is eating the stake she cooked, she asks him, "You got any whiskey? How "bout giving me a glass of whiskey?” (SHANLEY, 1988, p. 40). The description reads, "Loretta picks up her glass and swallows a healthy dose" (SHANLEY, 1988, p. 40). Later on, "Loretta pours herself another shot" (SHANLEY, 1988, p. 40) and finally, "(she pours them both another drink)" (SHANLEY, 1988, p. 40). Loretta's family is Italian-American; from an ethnic group in the margins of the American society, she is used to drinking generous quantities of alcohol, which is typical of an 'unruly' woman. Her unruliness is also expressed in the above-mentioned scene in which she slaps Ronny in the

author, but rather expresses the different 'voices' often contradictory, that permeate the text. The polyphonic novel is also characterized by a carnivalistic standing that questions the power of the dominant ideologies and institutions and thus the reality of any system ${ }^{6}$. 'Carnivalesque' refers to a literary mode that subverts and liberates the assumptions of the dominant style or atmosphere through humor and chaos. 
face when she is trying to make him forget her. Yet, as Janhavi Mittal argues, "The label of monstrosity is contingent on an implicit recognition of monstrosity by its corresponding society" (MITTAL, 2013, p. 105) and what might be perceived as monstrous by the American society might not be equally perceived by the Italian culture.

\section{Conclusion}

Moonstruck can be thus read as a 'textual production' grounded on a critical and cultural approach that exposes mechanisms of control of certain institutions, such as those of the church, with its mechanisms of symbolic control, presents a form of resistence and confronts the canon, deviating from hegemonic forms, and reflects upon the status of the emergence of new subjects once invisible, namely women as a minority. In Moonstruck the canonical values are, therefore, subverted and women are no longer 'framed' but empowered. Certain performances are definitely deconstructive of 'framed' representations and the roles played by Cher and Olympia Dukakis in this romantic comedy undoubtedly prove this assertion. Loretta and Rose Castorini, the main female characters in this story, are definitely not helpless and not in need to be rescued by a strong male character. Loretta is the type of women who teach other women to be sexy and feminine at the same time and be completely in control because every clothing choice you make is a form of communication in which you are conveying something. Furthermore, parodically, the men in the story are the ones in stronger need of female support. Moonstruck is a very good example of how popular culture in general, and iconic celebrities in particular, can have an important say in the deconstruction of traditional gender representations and ultimately strongly contribute to the empowerment of minorities. As Kathleen Rowe rightly claims, Cher's character is "a paradigmatic woman on top, enhanced by the strong unruly off-screen presence Cher brings to the part" (ROWE, 1995, p. 204). 
Orquídea Cadilhe

\section{References}

BAKHTIN, Mikhail. Problems of Dostoevsky's Poetics. In C. Emerson (Ed. \& Trans.), Theory \& History of Literature Vol. 8. Minneapolis: University of Minnesota Press, 1999.

BERNHEIMER, Kate. Forward. In S.R. Bobby (Ed.), Fairy Tales Reimagined Essays on New Retellings (p. 31-43). Jefferson, North Carolina, and London: Company, Inc. Publishers, 2009.

CARROL, Sandra, Wagner, Peter, Pretzsch, Birgit (Eds.). Framing Women: Changing Frames of Reference from the Enlightenment to Postmodernism. Tübingen: Max Niemeyer Verlag, 2003.

CARTER, Angela. The Company of Wolves. In A. Carter, The Bloody Chamber (p. 1-42). London: Vintage Carter, 2006.

DANTE, Alighieri. Inferno (S. Lobardo, Trans.), Indianapolis: Hackett Publishing, 2009.

DAY, William. Moonstruck, or How to Ruin Everything, In Kenneth Dauber and Walter Jost (Eds.). Ordinary Language Criticism: Literary Thinking after Cavell after Wittgenstein (p. 315-328). Evansville: Northwestern University Press, 2003.

FORD, Elizabeth, MITCHEL, Deborah. The Makeover in Movies: Before and After in Hollywood Films, 1941-2002. Jefferson, North Carolina, and London: McFarland \& Company, 2004.

HAASE, Donald (Ed.). Fairy Tales and Feminism - New Approaches. Detroit: Wayne State University Press, 2004.

HUTCHEON, Linda. The Politics of Postmodernism. London \& New York: Routledge, 1989.

KRAMER, Heinrich, Sprenger, Jacob. The Malleus Maleficarum (M. Summers, Trans.). New York: Manchester University Press, 2007.

JOYCE, Christa Mastrangello. Contemporary Women Poets and the Fairy Tale. In S.R. Bobby (Ed.), Fairy Tales Reimagined - Essays on New Retellings (p. 3143). Jefferson, North Carolina, and London: Company, Inc. Publishers, 2009.

MACEDO, Ana Gabriela. Visual and Literary Narratives of Dissent. Unframing women and representation. Journal of Romance Studies, 15(3), 83-98. doi: 10.3167/jrs.2015.150307, 2015. 
MACEDO, Ana Gabriela. Who will make me real? Mulheres, arte e feminismos, modos de ver diferentemente. Vista - políticas do olhar, 1, 93-107, 2017.

MILTON, John. Lycidas. Madras: Orient Longman. Minneapolis: University of Minnesota Press, 1983.

MITTAL, Janhavi. Postmodern Potencies: Interrogating the Monstrous Sign in Contemporary Society. In A. Stasiewicz-Bieńkowska \& K. Graham (Eds.). Monstrous manifestations: Realities and the Imaginings of the Monster. Oxford: Inter-Disciplinary Press, 2013.

ORENSTEIN, Catherine. Dances with Wolves - Little Red Riding Hood's Long Walk. In: the Woods, Ms. Magazine, 2004.

ROWE, Kathleen. The Unruly Woman - Gender and the Genres of Laughter. Austin: The University of Texas Press, 1995.

SHANLEY, John Patrick. Moonstruck. Unpublished manuscript, 1988. https://www.raindance.org/scripts/old-library/Moonstruck.pdf

TIFFIN, Jessica. Marvelous Geometry - Narrative and Metafiction in Modern Fairy Tales. Detroit: Wayne State University Press, 2009.

WARNER, Marina. From the Beast to the Blonde - on Fairy Tales and their Tellers. London: Vintage, 1995.

ZIPES, Jack. The Trials and Tribulations of Little Red Riding Hood. New York \& London: Routledge, 1993.

Recebido em 29 de setembro de 2020.

Aceito em 30 de outubro de 2020. 